\title{
MANAGING IT AS A BUSINESS: THE LUTCHEN'S GAP IN THE 100 TOP ORGANIZATIONS BASED IN BRAZIL
}

\author{
Sergio Alexandre Simões \\ Leonel Cezar Rodrigues \\ Emerson Antonio Maccari \\ Nove de Julho University - UNINOVE, Brazil \\ Mauricio Fernandes Pereira \\ Federal University of Santa Catarina - UFSC, Brazil
}

\begin{abstract}
A common problem in IT management involves the lack of business vision on the part of IT executives who align IT to the strategic assumptions of the company, but forget the tactical functions of the former, managed as a business. This is known as the Lutchen's gap. Because of its importance in the context of IT management, this paper is a complementary approach to the preceding one from Rodrigues et al. (2009) and aims at identifying the Lutchen's gap presence in the management of IT among the 100 top companies located in Brazil. To do this, we proceeded to a description of the profile of IT management in these companies, controlled by the executive board. We used a questionnaire filled out by IT executives, containing 77 questions covering the four functions of IT in a company. The main results indicate that: (a) In the IT's Alignment function, the design of IT reveals dichotomies between business and IT objectives (b) In the IT's Management function, the IT's budget is oriented toward ensuring "delivering" abilities to IT services and differing in the methods of cost control, ranging from apportion by volume, overheads and by ABC cost, (c) in the IT's Deliver function, evidence suggests that IT is managed as a business enabler; and (d) in the IT's Quality and Safety Assurance, IT executives monitor quality and safety events, but are limited to IT's basic operations. In conclusion, in the companies surveyed, IT is seen much more as an" on-demand solution provider", rather than as an instrument of innovation and competitiveness enabler for organizations.
\end{abstract}

Keywords: IT Strategy; Innovation; IT as business; Lutchen Gap.

Manuscript first received/Recebido em: 14/05/2011 Manuscript accepted/Aprovado em: 22/07/2011

Address for correspondence / Endereço para correspondência

Sergio Alexandre Simões, Mestre pela Universidade Nove de Julho - UNINOVE, sergioalexandre.simoes@gmail.com

Leonel Cezar Rodrigues, PhD Doutor pela Vanderbilt Unviersity Diretor do Programa Interinstitucional de PG em Administração da UNINOVE Professor do Programa de Mestrado e Doutorado em Administração da UNINOVE, Av. Dr. Adolpho Pinto, 109 Barra Funda - São Paulo-SP, Brasil, Email:leonel@uninove.br

Emerson Antonio Maccari, Doutor pela Universidade de São Paulo - FEA/USP Diretor do Programa de Mestrado Profissional em Gestão de Projetos - UNINOVE - Universidade Nove de Julho, E-mail: maccari@uninove.br

Mauricio Fernandes Pereira, Pós-Doutorado em Sociologia Economica e das Organizações pela Universidade Técnica de Lisboa, Professor do Departamento de Ciências da Administração da Universidade Federal de Santa Catarina-UFSC, E-mail: mfpcris@gmail.com 


\section{RESUMO}

Um problema comum em gestão de TI, apontados pelos especialistas, envolve a falta de visão de negócio dos executivos de TI ao alinharem seus departamentos com as premissas estratégicas da empresa e esquecerem-se das funções táticas da TI, onde esta poderia ser gerida como um negócio. Esse é conhecido como o gap de Lutchen e por sua importância no contexto da gestão da TI, este artigo é complementar ao artigo de Rodrigues et al. (2009) e visa identificar a presença do gap de Lutchen, na gestão da TI entre as 100 maiores empresas sediadas no Brasil. Para tanto, procedeu-se a um levantamento do perfil da gestão de TI nessas empresas, na visão de seus executivos. Utilizou-se um questionário, respondido pelos executivos de TI, contendo 77 perguntas que varrem os quatro fundamentos da função da TI na empresa. Os principais resultados indicam que: (a) na função Alinhar, o desenho da TI apresenta dicotomias entre os objetivos dos negócios e os da TI; (b) na função Gerir, observa-se que os orçamentos de TI orientam-se para garantir a capacidade de "entrega" dos serviços de TI e diferem nos métodos de controle de custo, variando entre rateios por volume, overhead e custo $\mathrm{ABC}$; (c) na função Entregar, as evidências indicam que a TI é gerida como uma capacitadora de negócios; e (d) na função Garantir a Qualidade e Segurança, muitos executivos de TI monitoram eventos de qualidade e segurança, mas limitam-se às operações básicas da TI. Em conclusão, o que se observa nas empresas pesquisadas é que a TI é vista como um sistema "fornecedor de soluções," sob demanda, dos negócios, mais do que como um instrumento capaz de garantir inovação e capacidade competitiva para as organizações.

Palavras-chaves: Estratégia de TI; Inovação; TI como Negócio; Gap de Lutchen.

\section{INTRODUCTION}

Currently, Information Technology plays a key role to generate improvements in productivity, competitiveness and in the profitability of organizations. In this context, IT management design can facilitate or could limit the achievement of organizational goals and objectives.

Lutchen (2003) states that, to be useful to corporate objectives, IT must be managed as a business. The problem, according to the author, is that in most organizations, IT management seems to pay attention to other aspects of organizational dynamics. According Lutchen, Chief Information Officers (CIOs) are directing their actions towards two opposite ends. To one end, they target at IT operating functions of the company; that is, planning and implementing of IT infrastructure. To the other end, they focus the strategic interests of the company, looking at the alignment of IT with business strategy.

However, IT should be in the middle of these two extremes as a mechanism to improve the enterprise's business performance. According to Lutchen (2003), to exercise the dichotomous roles in the business structure, IT leaves a large functional gap: to ensure the integration and differentiation processes of the organization's business. Lutchen calls the failure of this function as the IT delivery gap. The author argues that as an IT solution and business process flexibility inductor mechanism, IT itself should be managed as a business. To achieve this, IT should be, at the same time, determining the profile of the business and be fully integrated into the business transactional processes. Because it is a function that adjusts designs and ways to optimize resources and capabilities at the service of business processes, it is in fact a corporate function, but with a fundamental role for efficiency and effectiveness of business processes. 
Recently, Craig and Tinaikar (2006), based on the results of their research in the world's largest organizations show that IT is simply viewed, by most IT and Technology executives, as a solution provider demanded by business people. Companies where IT is used as a tool for business innovation and as a means of re-designing business are rare and almost nonexistent. Craig and Tinaikar (2006) research results also indicate that the majority of organizations still does not view IT as a mere instrument of delivering solutions. To manage IT as a tool for innovation, managers need to address or support a particular innovation strategy that is central to the dynamics of the enterprise. Having a clear innovation strategy, that is, setting technology as a basis for the business strategy is a quest that many organizations find it difficult to design and implement. Either way, Craig and Tinaikar's (2006) research results show that the functional performance of IT in the organization confirms Lutchen's (2003) thesis about the gap of IT as a tool for business differentiation.

On the one hand, business executives want and need IT to help them achieve business goals. On the other hand, IT executives, more subservient to the structures and procedures of the organization, understand business goals as the only thing to be done. This ultimately determines the format of the IT's management that focuses on operational functions and define this as the main focus of IT executives. Additionally, this focus limits the role of IT regarding business fundamentals.

In a broader context, yet to a lesser degree, IT is also used by business executives to support the formulation of their own competitive strategies. This is noticed in several works of renowned researchers, such as Abreu and Fernandes (2008), Rao (2002), and Prahalad and Krishnan (2002) that show the potential of IT to play a more critical role in the design of business that could be turned into a better macro performance for the organization. The findings of these researchers indicate that there seems to be a clear bias regarding the priorities of IT management and the implicit priorities in business management.

Major national organizations, because of their good performance, seem to have adjusted their business models using IT in efficient ways and giving the impression of absence or at least, the minimization of the functional dichotomy of IT in the organization. This problem, present in Lutchen (2003) "IT Delivery Spectrum" also shows to be a fact in these organizations, especially when one notes a great dispersion of IT's management and control methodologies (COBIT, ITIL, ISO etc.) in use. Using a variety of management methods does not imply that such methods are harmful to the IT's performance, but each method has a bias of specific administrative interest and does not necessarily fill the managerial gap above mentioned.

\subsection{Problem and Reseach Objectives}

The efficiency of IT management cannot be measured only by control parameters, applied to or used by IT executives. Instead, the performance of IT is also a function of perception of how useful and how compatible IT services are to their users and to the business of the organization as a whole. The vision of the role of IT in the organization, however, is not only a responsibility of business executives; it is mainly an IT executives' responsibility. The importance of IT regarding business efficiency has grown a lot in recent decades, and no leading organization can afford to disregard the role of IT to business performance. This issue shows how critical the relationship between business needs and the functions of IT in organizations is. Thus, would it be the case of IT management among the 100 top organizations based in Brazil? In what 
ways are the IT executives of these organizations working on the management of their areas in order to align, manage, deliver and assure the quality of IT services to their organization business?

In this context, the objective of this article, which is complementary to the article by Rodrigues et al. (2009), is to identify the Lutchen's (2003) IT delivery gap in the IT management of the 100 top companies headquartered in Brazil, distributed among the ten most representative economic sectors in the country. The Lutchen's (2003) IT delivery gap will be characterized through the IT management maturity criteria set out in COBIT (2010), involving the managerial design and the role of IT related to the needs of business organizations.

\section{LITERATURE REVIEW}

\subsection{IT Functions and the Lutchen's IT Delivery Gap aqui, Services Gap ou Delivery Gap?}

The literature review in this article involves the interpretation of Miles and Huberman (1994) on the Lutchen's (2003) IT delivery gap associated with the institutional functions of IT. To discuss more clearly, we propose a conceptual model, represented in Figure 1, which positions IT in the organization's administrative structure based on the functions that integrate the IT Delivery Spectrum (IT Enabling, M\&A Dues, and Leadership), proposed by Lutchen (2003) as the practical execution of IT functions. Here, we adapted Lutchen's concept of practical execution using surrogate activities in the spectrum - Alignment, Management, Services and Quality and Safety as key functions of IT. The way IT delivers in these functions tells us the presence or even the origins of IT services or delivery gap.

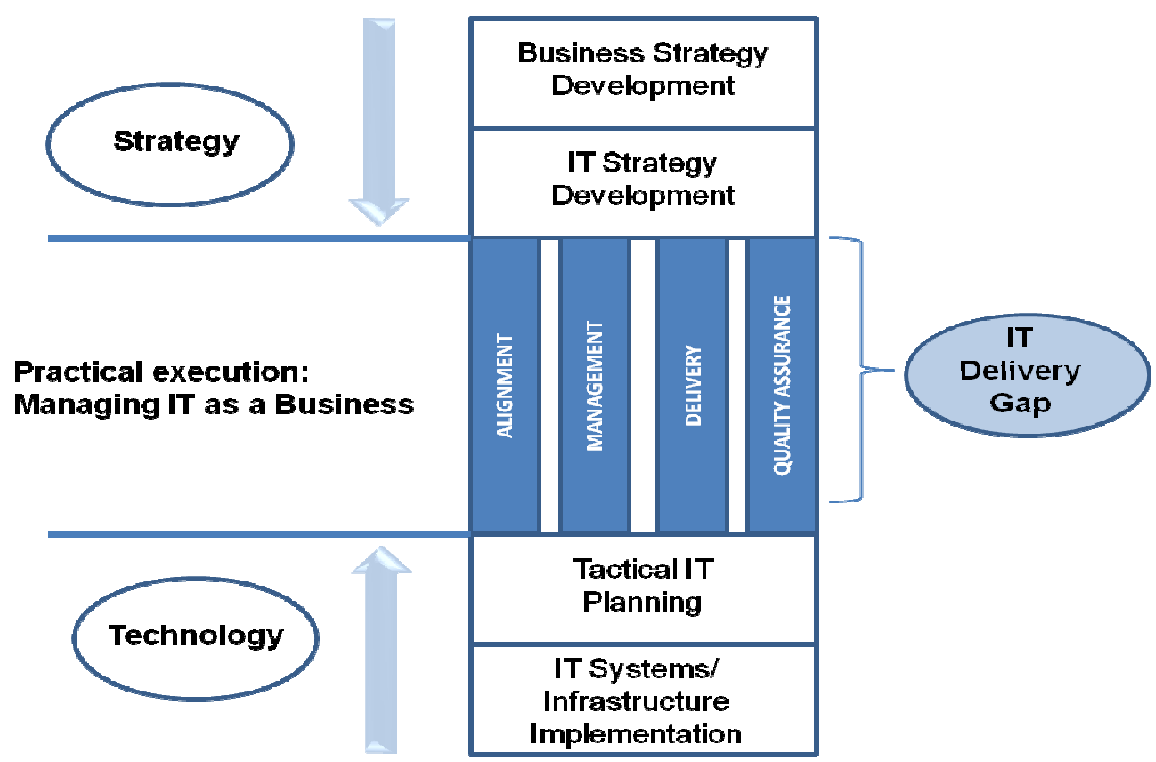

Figure 1: Structural Functions of IT

Source: Adapted from the IT Delivery Spectrum (LUTCHEN, 2003).

To understand the concepts in Figure 1, one must consider, by definition, the involvement of three distinct contextual event areas - strategy; technology; and IT gap. 
These areas determine the profile of the IT management in the majority of organizations:

(1) Strategies Area - Hierarchically above the "spectrum of IT Delivery", the formulation of IT strategies occurs, which should be aligned with major corporate strategies, but mainly with business strategies. By aligning with the corporate strategy and the company's business, IT can play a key role delivering applications to the internal demands and to the flexibility of business processes. IT strategy as a business, however, is motivated primarily by an internal view of IT management in order to reduce costs, increase process efficiency and service levels.

(2) Technology Base - the efficient delivery of IT services is conditioned by the technological composition of the organization, that is, by the technology available to IT in the company. To perform its functions, IT needs to manage technological resources and computer technology (hardware and related devices, and peripherals, software, telecommunications, systems, and data management and information) in an efficient and focused manner. Using the base of technology allows IT to perform its functions and effectively responds to domestic demands.

(3) IT Gap - The execution of IT functions (IT Delivery Spectrum) is where the translation and connection of IT solutions to business needs happen. Given its criticality to the business of the company, this is a strategic area in the context of IT management. It is in this area that the integration of systems, optimization of their applications, processes and controls development, management, performance indicators, and etc., should happen, ensuring that the alignment of IT with business strategies is not casual, but causal. Most often, however, this integration - between solution and the ability to meet business needs - does not happen in the best format and the IT loses its role as integrator and strategic to the business, leaving an open gap function, the Lutchen's gap.

The IT functions pointed by Lutchen (2003) are where one can observe that IT plays its role in the direction of changes and in the performance of organizational dynamics. Therefore, it is important to review each of the functions, here called Alignment, Management, Services and Quality \& Assurance, discussing concept, accumulated knowledge and understanding their implications for the business.

\subsubsection{Alignment}

Although executives of IT in general ensure the IT alignment with business strategies, the results provided by Prahalad, Krishnan's (2002) research, among 500 business executives from organizations around the globe, are against the existence of alignment between IT and the strategic interests of the business. This research evaluated the alignment of IT under five parameters, intrinsic to the business nature (Degree of changes in the Industry, Strategic Management, Ability to change the organization, Quality of infrastructure and People's Collaborative capacity within the Organization) 
on a scale ranging from 0 to 5 , being 5 fully aligned. The responses of business executives demonstrated a low degree of alignment (a 2.5 mean), indicating that alignment of IT with business strategies, in the companies studied, is far from desirable.

The intense competition among companies requires from IT special attention to align goals and activities with strategic business objectives. This alignment is an important driver of organizational success. It is only through this alignment that the mission, the goals and the business strategic plan (BSP) can be effectively shared and supported by the IT Strategic Plan (ITSP). The SBP is a set of objectives and goals that help organizations use and optimize allocation of resources to develop special skills and competencies that make them particularly competitive (LOBLER et al. 2008). In addition, Rezende (2002) observes that the SBP is a dynamic and iterative process to induce the setting of objectives, policies and strategies of the organization.

The ITSP, according to Weill; Ross (2004) provides an overview of concepts, methods and processes, technologies and tools necessary to facilitate the implementation of the business strategy. The ITSP also supports the decisions, the business actions and respective processes, generating direct benefits to the business itself.

The alignment between the ITSP and the BSP can be decisive for the competitiveness of the company. Thus, according to Luftman (2003), Zorello (2005) and Abreu and Fernandes (2008), a good level of alignment means that the organization applies IT resources in a timely and adequate manner, making it consistent with the goals, the needs and the business strategy of the company.

Craig; Tinaikar's (2006) research shows that IT plays different roles in organizational processes, especially in cases where the ITSP is aligned to BSP, to achieve specific objectives. The authors grouped the influence of IT on business into three roles, based on the relationship and support it provides to products and processes: (a) service provider, (b) tool for innovation, (c) rule-breaker business.

(a) IT as a service provider. This is the most common role that IT plays within the organization. As a service provider, IT primarily focuses on meeting the needs of administrative tasks and of information for the organization. IT keeps itself apart or away from business without a clear and direct involvement in the processes and in their final performance.

(b) IT as a tool for innovation. This is a less common role played by IT, however, a more desirable one. It is a very role difficult to play because it requires a combination of capabilities and IT resources in order to give the organization greater ability to innovate. In this case, IT aligns well with other internal functions such as knowledge management, organizational learning and corporate entrepreneurship and has become a tool to support process and products innovation, and to support flexibility in transactional business processes.

(c) IT as a competitive differentiation. This is the most rare and unusual role of IT. It happens when IT, through new solutions, forces the redesign of a business base (technological and transactional), distinctively from the usual format a business is built in a sector. In this case, IT is what determines the size, shape, products and business processes. IT also becomes the base for 
the business model based on its own technological capabilities and taking a proactive role in determining a new business format.

It is clear that the alignment of IT with business strategy gives to IT a more proactive and innovative role in business. It is clear from the arguments of Lutchen that IT must be managed as a business, requiring that CIOs facilitate business strategies, as suggested by Prahalad (2006), and from the observations of Craig and Tinaikar (2006), that IT has distinct roles in the model and competitiveness of a business. However, it remains unresolved the difficulty of transforming CIOs, usually with expert advice on business executives, as suggested by Lutchen (2003). More recently, Takanen (2008) also points out as an additional difficulty the fact that CIOs do not participate in the planning and in the decision making process of strategies formulation in the organization, because of the underprivileged hierarchical position of IT in organizations. A position close to the top management would actually help in more efficient alignment actions to achieve the company's strategic goals, as well as in a more efficient execution of its functions in the organization.

\subsubsection{IT Management}

Good IT management is associated with the dynamic synchronism between IT and business strategies. As pointed out by Rodrigues et al. (2009), the dynamic synchronism of strategies, however, is not enough to ensure the effectiveness of IT functions regarding business interests, according to Shpilberg et al. (2007). It is necessary beware of the alignment traps. By alignment one means the degree of commitment of the IT group to business priorities, resource allocation and execution of projects, as well as the delivery of solutions consistent with business objectives. The traps of alignment appointed by Shpilberg et al. (2007), however, are associated more with problems of inefficiency due to incompetence in the IT group than with problems of alignment itself. For example, the most frequent cases of delay in IT projects usually refer to problems associated with the incapacity of the staff than necessarily with the problems of IT solutions design. In these cases, effectively executed IT management, noting the proper complementarity of administrative functions, should ensure the effectiveness of IT institutional functions.

In addition to the normal aspects of managing IT, management processes must consider investments in IT as a management tool to drive and to support the alignment of IT with business strategies. According to Craig and Tinaikar (2006), as pointed out by Rodrigues et al. (2009), one of the most efficient ways to identify this alignment is to consider investments to "stay in the race," to "win the race" or to "radically differentiate" in the business. To stay in the race, investments simply focus on the capacity of IT to respond to local demands. To win the race, investments consider transforming IT into an innovation tool. And to radically differentiate themselves, investments attempt to make IT a base to radical or even disruptive innovation in business.

Even from distinct approaches, the understanding of the strategic management of IT, analyzed by Craig and Tinaikar (2006), keeps similarities to the understanding of IT management by Lutchen (2003), in the sense that, for the authors, IT must be managed efficiently regarding its functions in business, independently of the role 
intended to it in the context of the organization. The fact is that, as shown by Craig and Tinaikar (2006), IT should be playing a much more prominent role for business innovation than it actually does. Research results show that in the majority of the firms, IT plays a secondary role, being a mere solution supplier. And so, IT works as a common department of internal routine, much more concentrated on avoiding and explaining its operating costs than on distributing them over the demanding business departments (LUTCHEN, 2003). IT seems to be less concerned to demonstrate its value, based on the investment return to the business coming from its innovative role than to justify its costs (CRAIG; TINAIKAR, 2006).

On the other hand, Marwaha et al. (2005) research results, from responses of 9.345 IT executives worldwide, indicate that $53 \%$ of these executives recognize innovation as the most important ability to grow their business. There seems to be a dichotomy between actions and the managerial thinking of IT executives. Despite claiming that IT constitutes a powerful tool for business innovation, IT executives act, routinely, as if the only IT function were to provide automation and productivity solutions to the enterprise. Although these actions may have explanations in their respective contexts, the dynamics of the business concept, which requires constant innovation, seem not yet touched IT executives in their day to day managerial practice.

\subsection{Services}

Speed, productivity and innovation in delivering are hard to be built characteristics because of their conflicting natures. Speed and productivity are congruent, but adding ability to innovation, simultaneously, seems to be dichotomous. Marwaha, Willmott (2005) suggest a steady migration of levels. Once identified, innovation needs to migrate quickly to business standards. Thus, innovation as a solution to a process or a new product must keep a strategy aligned with business strategy to ensure achievement of goals.

The adoption of innovative processes to help business performance by giving higher efficiency to IT services, however, must be orchestrated in a consistent manner across the organization. According to Correa (2006), IT Governance is the mechanism that can provide a framework linking IT processes, resources and strategies to the strategic objectives of the organization. IT governance is therefore essential to ensure efficiency improvements in the processes of the organization aiming at speed, productivity and innovation.

Once the cycle of governance and best practices are provided by the management of IT processes, it is necessary, according to Weill and Ross (2004), to explore the potential of macro processes of Management of Demands and Portfolio, which is essential to establish the cycle of Governance and evaluate the results of IT service delivery.

The IDC study (2006) concluded that organizations that are part of the Global 2000 Group are using management and prioritization of projects and programs of IT to gain a competitive edge and increase efficiency. According to the IDC (2006), the IT portfolio management is used to define, assess, control, monitor and optimize tasks and resources needed to plan and complete a project, also in addition to managing the portfolio of all projects of the organization, including the analysis of "what if" in projects proposed or approved, but not yet running. This is the process of collectively analyzing costs, risks and benefits of new projects in the context of ongoing investments 
in order to make better decisions and investments. In this phase, it is important the definition of roles and responsibilities of each player (Borland, 2006).

In short, what can be inferred from the observations and findings in the authors cited, is that in terms of Services, the focus is on how to accelerate and increase innovative capabilities of organizations through consistent delivery of IT services. This really generates the context for the argument of this article. That is, speed and innovative capacity of business are reflections of how IT should be managed as a business, as argued by Lutchen (2003), involving documented processes and rules, automated and disseminated through the company, in accordance with the best practices, bolstered by parameters, indicators and measurable metrics.

\subsection{Quality \& Security Assurance}

Quality and Security in the processes of IT management are associated with the efficiency and effectiveness in Service Level Agreements, known as SLA. For a better understanding, it is important to clarify the difference between the concepts of efficiency and effectiveness in the context of SLA, according to Albertin and Sanches (2008):

- Efficiency: It is related to the provision of IT services and costs associated with planned deadlines. It is associated with the way IT services are delivered to users, according to agreed quality standards. It involves the search for alternative solutions to meet the demands within the level of pre-planned resources. Efficiency is usually measured using unitary costs and using the service levels offered by IT. It involves obtaining economies of scale and use of standardized solutions versus specific solutions.

- Efficacy: It is about the ability to provide effective solutions to the demands. It means being able to meet the needs of users, regardless of the level of difficulty of the demand. Efficacy is linked to the priorities of IT investments and relates to the evolution of IT solutions. Efficacy also relates to the benefits after the implementation of the solutions that meet or exceed original expectations. The model of IT services is tailored to the needs and goals of users.

It is also important to define here the understanding of Service Level Agreements that seek to parameterize the quality of products and services of IT. Albertin and Sanches (2008) define the Service Level Agreement as a contract that defines parameters that a service provider makes available to clients, specifying the performance measures for hired services. SLA also defines commitments, responsibilities and limits applicable to both parties.

According to Abreu and Fernandes (2008), it concerns to the management of IT performance, the setting of performance objectives, the creation and implementation of indicators, the monitoring, the decisions considering results measured / obtained and the continuous improvement actions arising from the process of monitoring and control. In practical terms, Weill and Ross (2004) suggest that the management of IT performance should done based on four main factors and their relative importance for each 
organization: the use of IT-oriented efficiency and cost control; the effective use of IT to use its assets, the effective use of IT for business growth; and the effective use of IT for business flexibility.

Standardizing the measurement of IT performance, however, typically follows the version 4 COBIT, performance framework (ITGI, 2010). This is a structure recognized and used by organizations as a model for the management of IT performance. It contains processes and controls objectives and for measuring and monitoring IT in organizations that eventually can be measured (or calculated) through the balanced scorecard (BSC) and / or specific audits, as the Statement on Audit Standard 70 (SAS70).

According to Brege, Brehmer and Rehme (2008), the use of BSC as a tool for performance measurement and control is highly useful in IT management, especially in cases of outsourcing encompassing more strategic and long range functions. The main reason for using the BSC in these cases is that long-term contracts can have a direct relation with and affect activities related to value creation, innovation and product development. Therefore, it is essential for executives to have a more corporate and strategic performance vision of these contracts. The application of the BSC can help obtain and evaluate the usefulness of these indicators.

Finally, to ensure the quality of IT services, it should be noted that the performance of IT in terms of quality and safety of services can be measured by the combination of the ability of IT governance mechanisms, which enable the desirable behavior of IT in the organization, and the level or degree to which these performance objectives for quality and safety requirements are met in the business arena.

\section{METHODOLOGY}

The research framework that guided the questionnaire followed the premises of Lutchen's (2003) spectrum of IT delivery, as we expressed by: alignment, management, service and quality \& security. The design has followed the assumption that a strategic group of leading organizations is responsible for the performance profile and trends in its economic sector. Porter (1986) defines strategic group as a set of similar organizations within a sector, and different from others outside this sector, in one or more key dimensions of strategy. Thus, the sample was intentionally chosen to form a strategic group representing ten different economic sectors in the Brazilian economy. To select the research sample, we used the biggest and best companies located in Brazil, listed in the Guia Exame das Maiores e Melhores, published in July 2008.

The answers to the 77 questions constituent of a disguised and semi-structured questionnaire was sent, via Internet, to the CIOs of the 100 selected companies. The objective was to characterize the management of IT in terms of its alignment with business strategy, in terms of profile management, in terms of ways to deliver IT services, and in terms of quality and safety assurance of IT services. The characterization of these four functions was studied for this article, in terms of the maturity of IT management, according to the parameters and indicators listed in the version 4 of COBIT (ITGI, 2010). In COBIT, the resultant of the four functions of IT represents the strategic alignment of IT with the business, expressed as levels of maturity in IT (Lobler et al., 2008). Thus, by knowing the functions and expressing 
them as the level of alignment of IT with the business objectives, we are expressing the COBIT maturity level and, at the same time, the profile (or presence) of the Lutchen's gap. Thus, we utilized the parameters of maturity in IT management, as defined in COBIT, version 4 (ITGI, 2010), since COBIT has been adopted as the reference model in business worldwide, because it is recognized internationally and help understand and manage IT risks.

The levels of maturity in IT management listed in COBIT are classified by Lobler et al. (2008) as the levels of alignment of IT to business, into five levels. As stated above, the levels of alignment are actually a result of the combined performance of the four functions cited by Lutchen (2003). Thus, the criteria indicate that the organizations that are at level 1 of maturity are those with a zero level of alignment, or virtually nonexistent alignment with respect to the business strategies.

At level 2 organizations are classified in a state of incipient maturity in terms of alignment with business strategies. Level 3 represents organizations with a maturity of IT alignment, focused and established. At level 4, organizations are characterized with a maturity managed at the strategic level. At Level, 5 organizations are classified with a level of IT maturity excellence, that is, at this level those organizations whose IT strategies are fully aligned with business strategies are classified. IT keeps all the processes of services fully integrated and documented in accordance with the market's best practices. For a better understanding of the maturity levels resulting in the search, we simplified the levels of maturity into three distinct groups: (a) incipient, (b) intermediate and (c) mature.

Thus, organizations classified with maturity levels in IT management between 1 and 2, in Lobler et al. (2008) classification, are here considered incipient in IT management. That is, in these companies, IT would not be managed as a business. The ones classified with level 3 of maturity are considered intermediate and have been shown to have elements of IT management as a business. Organizations that show maturity level between 4 and 5 are hereby classified as mature in IT use, because they are managing IT like a business.

Thus, the methodological design allows obtaining information about the results of the profile of IT management in the 100 biggest and best organizations located in Brazil. It is possible, therefore, to preview the profile of IT management regarding the presence of the Lutchen's gap, through the analysis and characterization of managerial practices used by IT to deliver services.

\section{RESULTS}

As indicated in the methodology, the organizations surveyed belong to the Brazil's 500 top companies, classified in the Guia Exame - Maiores e Melhores/2008. From this list, we selected the 10 largest in the 10 most economically representative industrial sectors of the country, that is, the 10 sectors with the highest contribution for gross domestic product of Brazil. In the characterization of the respondents, the degree of economic importance of the surveyed organizations is represented by the fact that $60 \%$ of them declare have revenues over US \$ 1 billion and only 3\%, under US \$ 200 million, annually. 
The survey data also indicate that, in terms of "momentum" of the business, 74\% of respondents note to be in process of expanding their markets, that is, directly increasing its relative share in the market's segment, or increasing the product portfolio to increase its presence in specific segments.

To provide focus and clarity to the great amount of the research findings and in keeping the purposes of this article, we decided to organize the results under the four functions of IT (Alignment, Management, Services and Quality \& Security). The data analysis considers only the main evidence of the functions of IT, to classify the management of IT in the organizations surveyed, according to the degree of maturity, using the parameters of the COBIT (IGI, 2010). Since the characteristics of maturity in IT management are based on the same elements of managing IT as a business, then we can establish a direct relationship between the degree of maturity in management of IT and the Lutchen's IT delivery gap.

\subsection{Function Alignment}

When questioned if the IT plan is formal, current, disseminated and aligned to the business, the responses of IT executives indicated that $63 \%$ have formal plans and IT is aligned with the strategic business plan (BSP).

It should be noticed, however, that $37 \%$ of IT executives did not execute a formal alignment or did not recognize the alignment as relevant, thus, generating a premise of significant misalignment of IT management with the mission and business objectives. It is presumed, for these cases, that IT does not support the business strategic plan (BSP). The evidence is the lack of use of management tools (Balanced Scorecard, for instance) determinants of the adherence to goals and actions of IT to business goals and actions. However, despite evidence of misalignment, IT can be exercising very well its unique role as a solution supplier through the implementation of operational activities and routine tactics. In this case, the focus may be in the management processes which are appropriate to technological and computational resources.

Graphic 1 shows that just under $40 \%$ of IT executives understand the importance of indicators and make use of them. For most IT executives (61\%) the Balanced Scorecard is not yet part of their management or even constitutes an instrument for aligning IT with the business. It should be noted, additionally, that about one fifth of the executives surveyed (18\%) did not even see this as a relevant tool for aligning IT with business strategy.
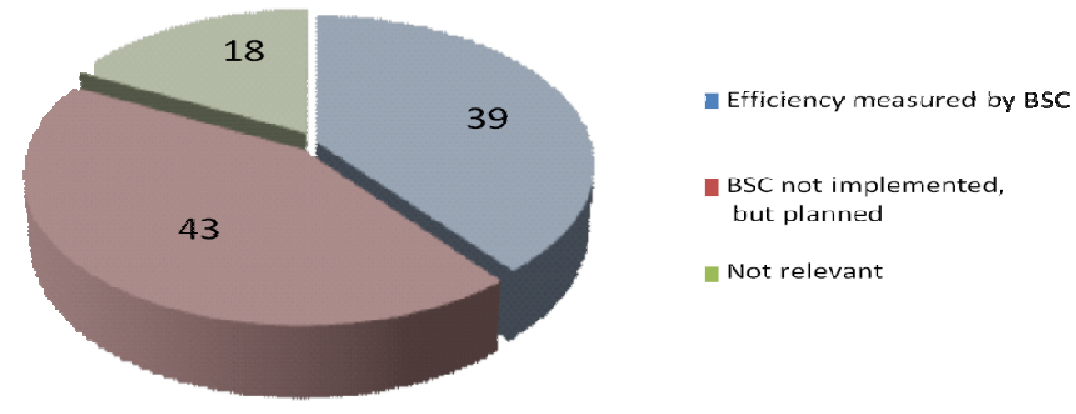

\section{Chart 1 - IT alignment based on Balanced Scorecard}


We also investigated the hierarchical location of IT, in the organizational structure as an important factor to characterize the strategic role of IT. Takanen (2008) has pointed the hierarchical position of IT as a barrier for IT to take an innovative role in the organization. The results indicate (Graphic 2) that the majority of IT executives is linked and reports directly to the CEO (Chief Executive Officer) in their organizations. This situation gives to IT a strategic participation in the decision making process of the organization, as IT leaders are at the same hierarchical level as business leaders are. This positioning also helps IT to exercise more effectively an innovative role or even being the cause of business-breaking rules, making more relevant the value that IT can add to products and services of the organization (CRAIG; TINAIKAR, 2006).

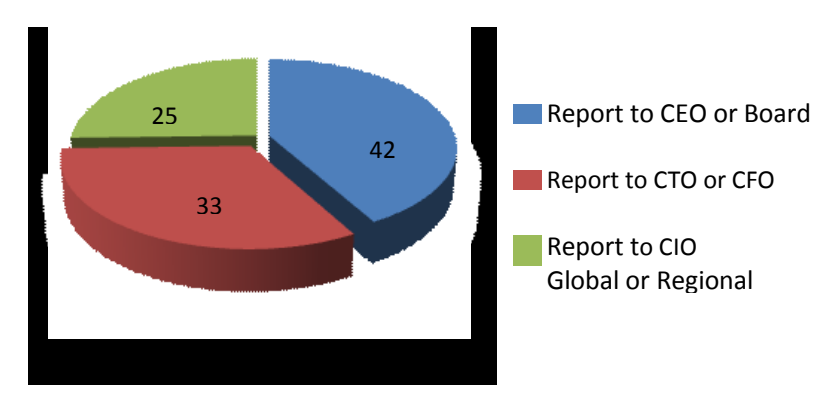

\title{
Chart 2 - Localization of IT in the Organizational Structure
}

With regards the leadership provided by IT, the survey shows that, normally, IT does not assume the leadership for internal changes, but shares the leadership for changing initiatives $(65 \%)$ with other areas of the organization. In other words, only in about one third of organizations surveyed, IT leads innovation initiatives. On the other hand, if added, the two percentages (28\% and 65\%) indicate that IT executives actively participate in over $90 \%$ of business change initiatives. This, in theory, allows them to practice the alignment of IT with the business, offsetting the possible problems arising from a less privileged hierarchical location of IT (Graphic 3).

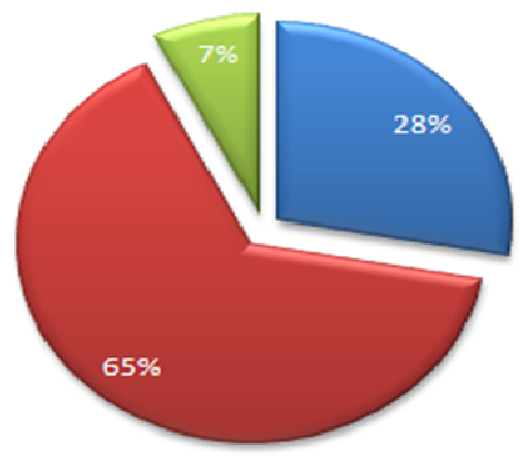

\author{
— Lead initiatives \\ - Share leadership with others \\ $\square$ Implement only
}

Chart 3 - Leadership in Innovation by IT 
Despite of IT executives share the leadership in internal changes and despite they indicate that IT plans are aligned with the mission and strategic business objectives, the survey results indicate that $43 \%$ of respondents do not use a performance measuring instrument (e.g. BSC) for IT. Considering that $61 \%$ (Chart 1) of IT executives do not use a performance measuring instrument, one can imagine that IT does not have performance standardized indicators and metrics common to the business area.

On the other hand, 57\% of IT executives say they have operational indicators in use (indicators which are documented, formalized, and disclosed as a routine), may not be feeding the performance indicators of the business properly. This might have strong implications for not alignment of IT with business objectives.

To characterize the alignment of IT management in organizations surveyed in relation to the degree of maturity according to COBIT (IGI, 2010), we considered relevant the positive responses to the existence of the following four essential elements: (1) IT Planning is aligned to the Business, (2) performance of IT measured by a standard instrument, such as the BSC, (3) subordination of IT to the CEO or Board, and (4) indicators and metrics to evaluate operating performance in use.

For each element, we identified the percentage of positive responses in the survey. For conversion to the scale of COBIT maturity level, which ranges from 1 to 5 , we used a normalization factor 20 for convenience. Thus, if all the survey responses were positive, we would have a level 5 maturity $(100 / 20=5)$, indicating that in the whole survey, organizations demonstrate to have IT strategies fully aligned with business strategies. For this research, the results of the Alignment function are shown in Table 1.

\begin{tabular}{l|c|c|c}
\hline \multicolumn{1}{c|}{ Elements of Alignmet } & Results & Normalization & Maturity \\
\hline Vector 1 - IT Alignment Plan & $63 \%$ & 3.2 & 3 \\
\hline $\begin{array}{l}\text { Vector 2 - IT Efficiency Measured by } \\
\text { BSC }\end{array}$ & $39 \%$ & 2.0 & 2 \\
\hline $\begin{array}{l}\text { Vector 3 - IT Reporting - CEO or } \\
\text { Board }\end{array}$ & $42 \%$ & 2.1 & 2 \\
\hline $\begin{array}{l}\text { Vector Performance } \\
\text { Indicator/Metrics - 57\% }\end{array}$ & & 2.9 & 3 \\
\hline
\end{tabular}

Table 1 - Level de Maturity Related to Alignment Function

Just a reminder, COBIT (ITGI, 2010) maturity scale, was associated by Lobler et al. (2008) to the functions of IT proposed by Lutchen (2003). In this study the scale was simplified to three levels: incipient, intermediate, mature. To fill the Lutchen's gap, the classification of the COBIT maturity level in IT management follows the criteria: Incipient: those with maturity level between 1 and 2. In this case, organizations do not to run IT as a business. Intermediate: those with maturity level 3. In this case, organizations have clear indications that are managing IT like a business. Mature: those organizations with maturity level between 4 and 5. In this case, IT is managed like a business. 
For the results of this research, the function Alignment has no clear indication that lies between the maturity level 2 and 3. That is, the organizations surveyed are partially incipient (and subordinate performance measures) and partly as intermediate (plane alignment of IT and operational performance indicators).

\subsection{Function IT Management}

Within the Lutchen's (2003) concept, the management functional gap appears essentially in the managerial practices of IT management. Managerial practices related to the logic of budgeting are the most critical. They involve the division of costs between units users so that IT is not seen as a mechanismtaken for granted, but as an essential management tool to increase the performance of the organization. As a mechanism that performs tasks for the distinct sectors - decreases operating costs increasing efficiency - IT costs must be paid by unit users.

The results of research on the practices of budgeting IT show a certain managerial pattern, focusing on three evidences. First, there seems to be a preference for allocation of resources (up to 10\%), among the majority of IT executives, over technologies in progress, updating the infrastructure, training and technological innovation (Chart 4).

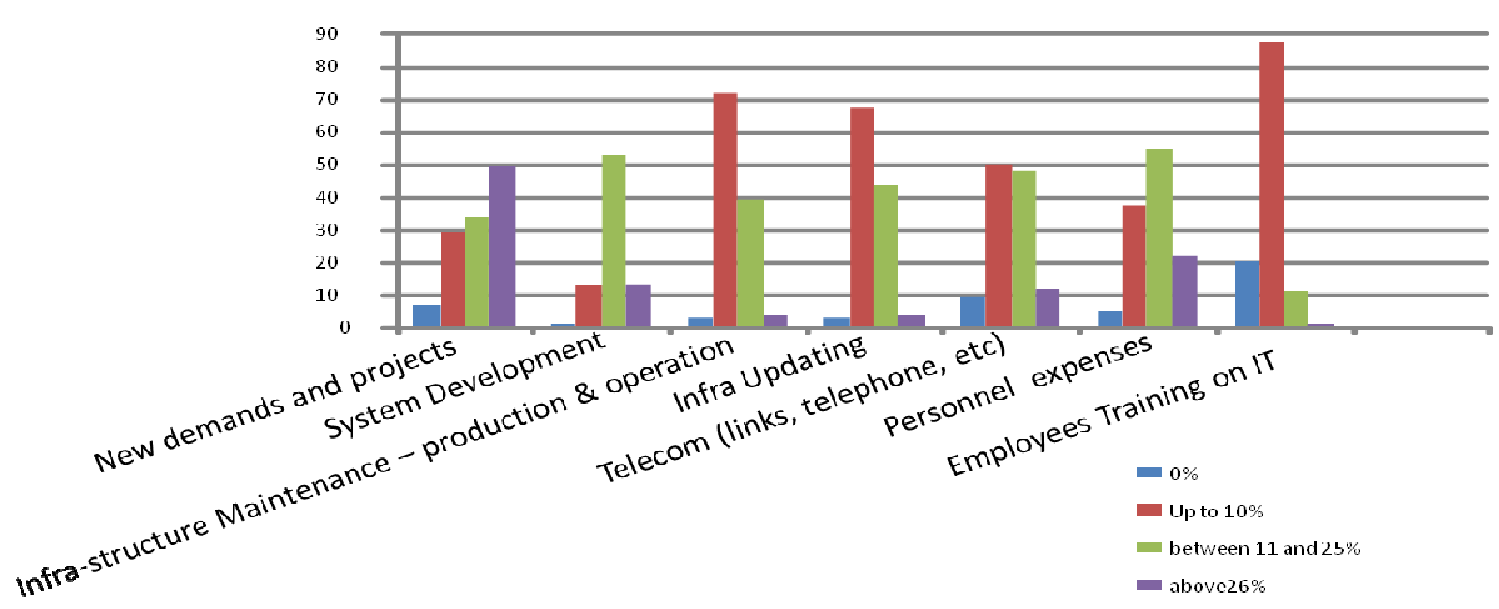

\section{Chart 4 - IT Budgeting Practices}

Second, a smaller set of executives spend on average $20 \%$ of their budget on systems and technologies in progress, on updating the IT infrastructure, and on personnel communication. Third, a small group (between $11 \%$ and $25 \%$ ) does not want to invest, or has zero budget for training / qualification in IT. Given the fact, however, that the numbers refer to the 100 top organizations based in the country, this percentage becomes significant. A New project is what gets the highest level of investment (over $25 \%$ ) in the budget of almost $50 \%$ of the IT executives surveyed.

One can notice that IT budgets are very focused on managing the IT day-to-day routines (maintenance of the park, Telecom, personnel costs, and the like). This form of resource allocation, as indicated by Craig; Tinaikar (2006), that resources are only to 
maintain the basic services of IT. In other words, IT management and the organization see IT as a solution supplier to the computational demands of their work routine. In our view, this format indicates that IT is being managed for implementing a business strategy based on the simple idea that the organization must just stay in the race (survive or maintain the position of the business).

It is relevant to the context of IT managing function, the way outsourcing is handled by IT executives (Chart 5). Being an important supporting role, both in readyto-use solutions, as well as at the level of costs for IT management, outsourcing can not be ignored or seen as an underlying matter in the administrative process. Despite the pronounced tendency of major international organizations in adopting outsourcing as a strategic alternative to the effective management of IT (Kaplan et al., 2006), we can notice, in this research, a certain conservatism in the allocation of resources for outsourcing (45\% allocate up $10 \%$ of budget on outsourcing).

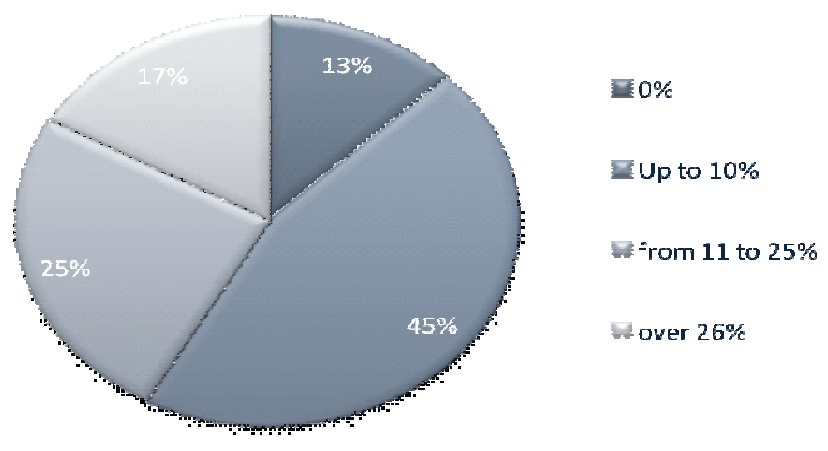

Chart 5 - Outsourcing Budget

It is also noticeable, in addition, that a significant share (13\% of IT executives) of the organizations surveyed allocates zero budget for outsourcing. The vast majority, however, allocates up to $10 \%$, however, $42 \%$ allocates over $10 \%$ of the budget for this activity.

The analysis of the activities contemplated by outsourcing shows that the biggest chunk of the budget aims at systems. The apparent reason for this fact may lie in the fact that IT, in search of greater responsiveness to the business demands, considers coding more application systems a priority in order to meet business needs. On an opposite end, there may be also greater "commoditization" of some technologies for system development which leads organizations to reduce their personnel, thus, reducing costs, but forcing them to look after knowledge cooperation for specific software that, scaling up, seems to be less expensive. 


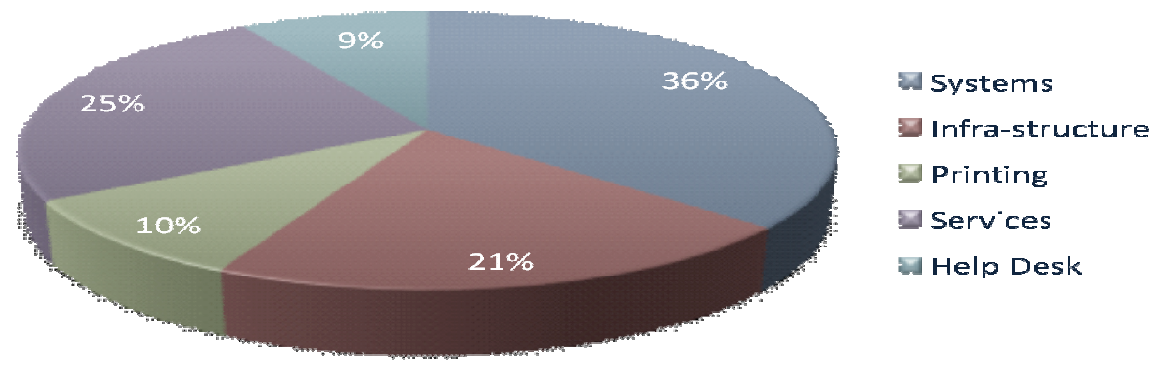

\section{Chart 6 - Budget Distribution of Outsourcing}

It is also interesting to observe the behavior of IT investments shown in the search results by Weill and Aral (2006) among the 140 largest organizations in the world versus the results of this search. For Weill and Aral (2006), areas of increased investment in IT are in the following order: infrastructure, transactional, informational and strategic. In this research, although not all percentages match the percentage of Weill and Aral (2006), the results confirm the same order of priorities of investments (Chart 7).

Also, according to the Weill and Aral research, the second area of investment (26\%), the informational area, coincides with the percentage of investments in Brazil. This area serves the tactical systems operations and became a major focus of investment, behind only the investments in infrastructure, possibly because of the concern of organizations with information systems. More recently, such systems have been refined to better serve the information needs on the competitive environment to support decision making in organizations.

Finally, it is also important to note that the strategic area of IT, the one that should worry about the value generation and incorporation of technological innovations, has received the least amount of investments in recent years, in both surveys.

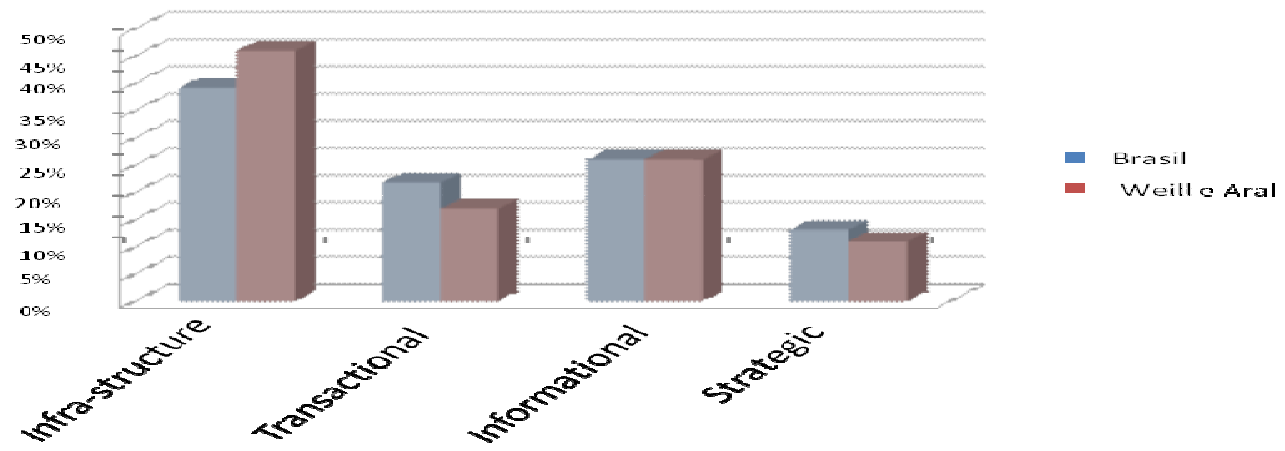

Chart 7 - IT Investments: World - Brazil

In assessing IT costs, one can notice that $31 \%$ of respondents indicate that IT costs, required to respond to the demands of a business area, are attributed directly to 
that area and other costs are prorated based on the outcome criteria or by users volume or by price list. Another $30 \%$ of executives say that IT costs are recorded as a cost center and distributed as overhead costs. Another 27\% indicates that their IT costs are prorated interchangeably by year or monthly, according to the consumption of IT resources and business areas. These costs are measured by cost drivers. Chart 8 shows the different format of allocating IT costs.

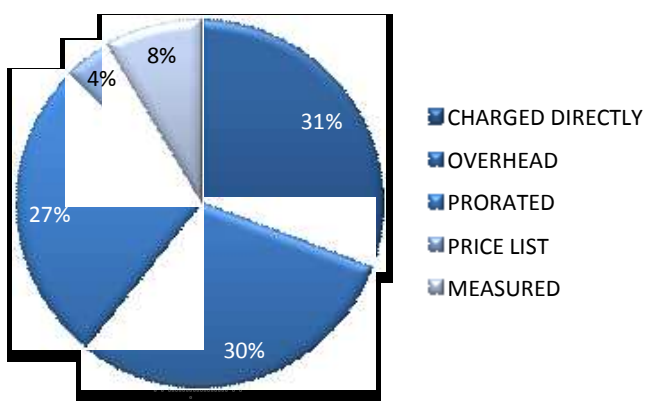

\section{Chart 8 - IT Costs Allocation}

To summarize the Managing function, we considered the same criterion of the previous function, and among the various findings of the research, some aspects may be relevant to demonstrate the performance of IT regarding its role for the business as follows: (1) the practices of project management; (2) Business Process Management (BPM); (3) the adoption of Capability Maturity Model (CMM); and (4) the adoption of Service Oriented Architecture (SOA) (Table 2).

\begin{tabular}{l|c|c|c}
\hline \multicolumn{1}{c|}{$\begin{array}{c}\text { Elements of IT Management } \\
\text { Function }\end{array}$} & Results & Normalization & Maturity \\
\hline $\begin{array}{l}\text { Vector 1 Practices of Project } \\
\text { Management }\end{array}$ & $64 \%$ & 3.2 & 3 \\
\hline Vector 2-Adoption of BPM & $53 \%$ & 2.7 & 3 \\
\hline Vector 3 - Adoption of SOA & $37 \%$ & 1.9 & 2 \\
\hline Vector 4 - Adoption of CMM & $53 \%$ & 2.7 & 3 \\
\hline
\end{tabular}

Table 2 - IT Managing Function: Elements of Managing it as a Business

The analysis of Table 2, containing the elements of the COBIT maturity (ITGI, 2010) for the IT Managing Function indicates that $3 / 4$ of the elements of this function tend to be performed in a more formalized way, which comply with the parameters of the level 3 maturity, intermediate. 


\subsection{IT Services Function}

IT services, also known simply as delivery, are analyzed based on 5 vectors: (1) Architecture and Systems, (2) Infrastructure Services, (3) Innovation, (4) ITIL Management, and (5) Portfolio Management. The first three vectors relate to the delivery processes of systems and applications, that is, meeting the needs of the business. The last two vectors relate to the standards and practices of IT governance. One can check in these two vectors if deliveries are structured based on accepted model of IT management, such as ITIL, COBIT, and PMI, among others.

For the first vector, called Architecture and Systems it becomes evident that the majority of IT executives have documented, monitored and measured the tasks inherent to this vector (architecture, operations analysis and systems development) - Chart 9. Intuitively, documentation, monitoring and evaluation functions of the tasks are minimal to ensure that IT, as a whole, executes the expected role it plays for the business. The survey results indicate that regardless of the economic segment of the organization, size or timing of the business, more than $70 \%$ of organizations surveyed demonstrated levels of maturity greater than 3 , on our measuring scale. Therefore, there is evidence that the vector architectures and systems in the organizations surveyed are in the mature stage.
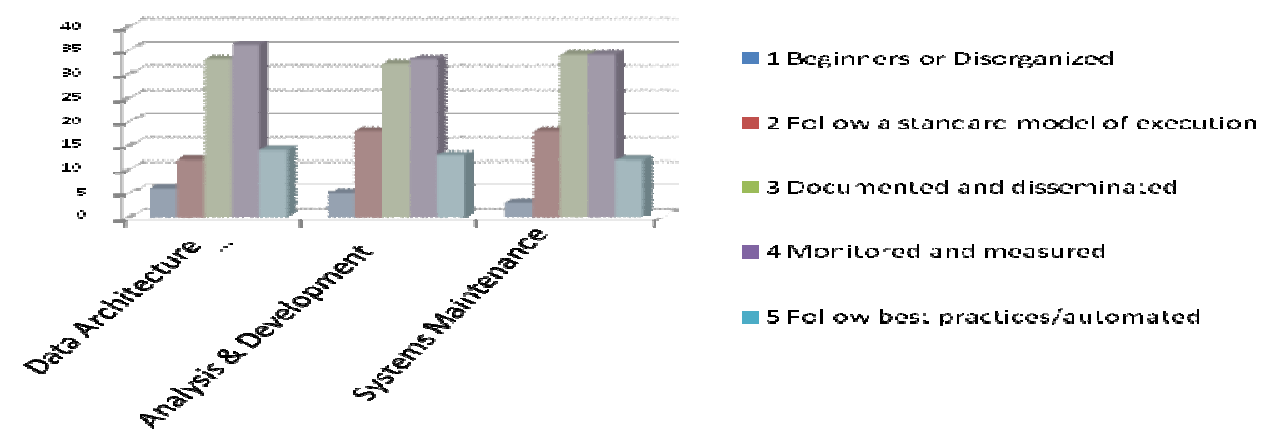

Chart 9 - Vector 1 - Architecture and Systems

For the second vector, called Infrastructure Services, the data are shown in Chart10. The results indicate that a small portion (11 to $13 \%$ only) of IT executives use the best market practices in an automated way. Few (2-4\%) are still unstructured for efficient management of the Infrastructure Services. In relation to the general IT services, the pattern is basically the same, that is, IT documents, monitors and measures, but it seems to have some problems to adopt the best practices. Chart 10 illustrates the information. 


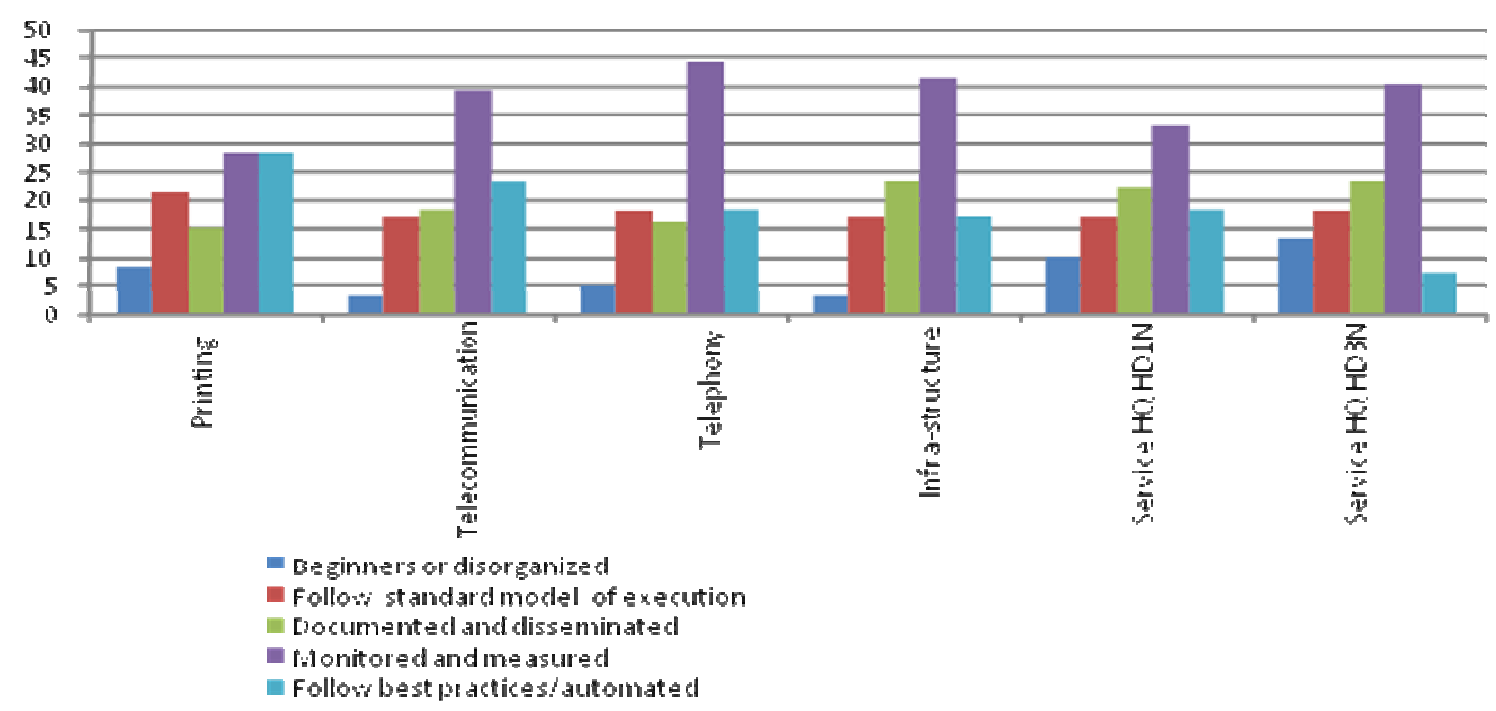

\section{Chart 10 - IT Infra-structure Services}

What we could note similarly to the first vector is the delivery of these services has, in more than $70 \%$ of organizations, level of maturity greater than 3 . Therefore, there is evidence (Chart10), that management process practices of Infrastructure Services are also mature in the surveyed organizations.

The third vector of IT Services researched was the innovation. Here ,we sought to know the level of concern of IT executives regarding innovation, that is, how IT plays the role of innovation and delivering innovation for business. The survey showed that about $20 \%$ dedicate not more than $5 \%$ of their time to innovation projects. Just over one third $(35 \%)$ of IT executives spend between $5 \%$ and $10 \%$ of their time on innovation and the other third devote between $10 \%$ and $20 \%$ of their time to innovation.

When looking at the role of IT in the innovation process - Chart 3 - one can see that for almost two thirds of IT executives, the role of innovation in business processes, products or services falls more as a partnership with business executives that appears as leadership actions in innovation, as already mentioned in Chart 3.

Still, in relation to the projects and technologies that IT is delivering to the organization, research shows that most IT executives (51\%) have a plan or simply do not plan to deliver innovation projects. Lutchen (2003) already alerted to the fact that organizations need to invest not only to maintain good service and IT projects, but also need to follow the best practices, in any case, to ensure innovation in products or processes that help to open new markets.

The fourth vector of IT Services refers to models of best practices and methodologies used by IT to deliver services and to ensure quality. This vector was verified by the IT governance in the organizations surveyed. According to Correa (2006), IT Governance is essential to ensure efficiency improvements in the processes of the organization.

IT Governance practices seek to ensure that the organization's expectations regarding IT are met, performance is measured, resources are managed within accepted standards and risks are mitigated. Hence, the use of standards and practices for IT 
Governance, structured around models of planning, organizing and managing IT, such as ITIL, COBIT, PMI, and others.

Overall, it looks like ITIL, PMI, COBIT and ISO27001 enjoy the preference of the majority of IT executives. One of the latest methodologies for the management of IT, The Open Group Architecture Framework - TOGAF (2009) - is virtually ignored by IT executives (3\% of respondents use the TOGAF). The low use of TOGAF may be due to the fact that it is still a recent practice of architectures and process management, though already in its ninth edition. The main methods for the management of IT used by respondents are shown in Graphic 11.

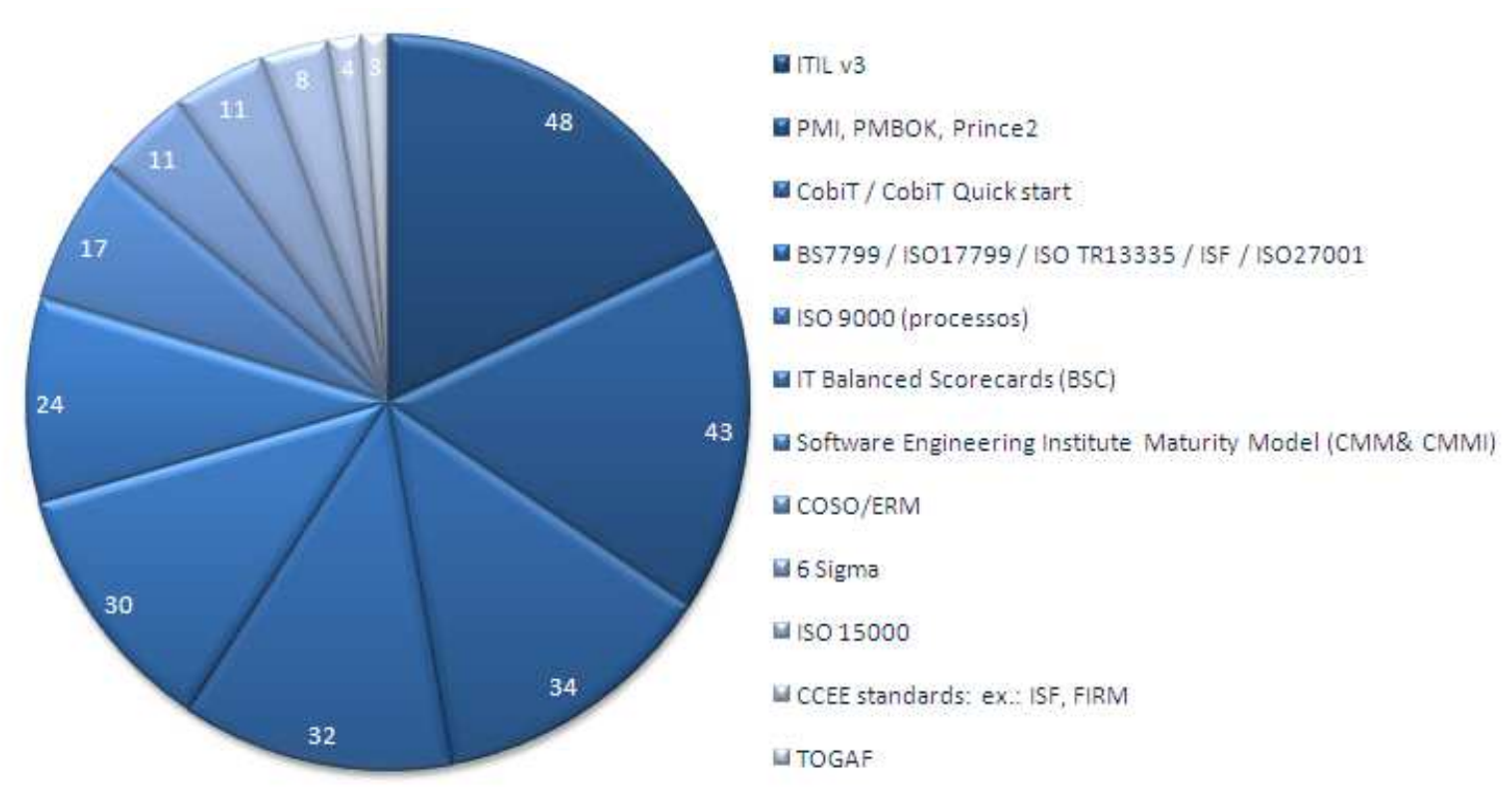

Chart 11 - Most Common Methodologies for IT Management

It is noticeable that there is a concern of IT executives to ensure that the adoption of standards of IT delivery is made through the tactical and operational discipline of tasks related to IT. Hence, perhaps, the fact that ITIL and PMI are the most widely used methods of governance in the organizations surveyed, in order to ensure speed and performance. Also there is a clear concern of the executives regarding the adoption of controls in line with corporate objectives in order to add value and keep the risk controlled through the use of management structures such as COBIT, BS and ISO.

As the fifth vector of analysis in the Services function, we evaluate the processes of demand and portfolio management, essential to establish the cycle of governance. The responses showed that the majority of IT executives $(80 \%)$ are capturing the demand for IT projects and services in a structured and documented way (Chart 12).

In the context, projects involving present portfolio systems, in most organizations surveyed (63\%), level of maturity above 3 (three), i. e, are documented and disseminated, and performance is monitored and measured continuously. Additionally, $16 \%$ of the respondents admit that the monitoring of these processes is made possible through the adoption of best market practices and automated tools. 

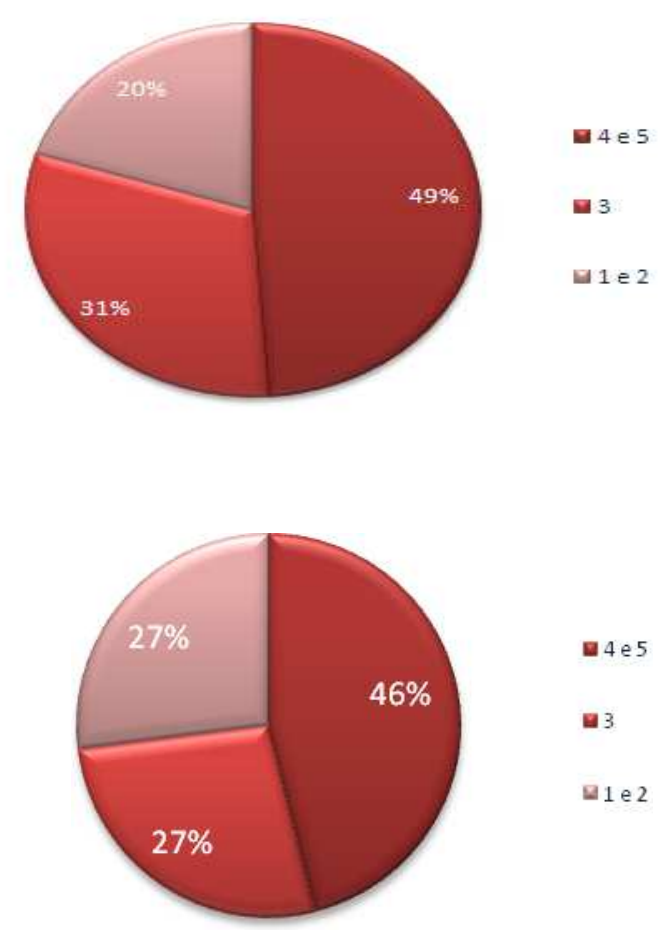

\section{Chart 12 - Demands and Portfolio}

It is important a reflection on these numbers, comparing them to the survey conducted by Jeffery and Leliveld (2004) with the 130 organizations of Fortune 1000. Leliveld and Jeffery (2004) identified four stages of maturity of IT portfolio management. Compared to the COBIT maturity levels (IGI, 2010), the vectors of IT Services function and considering the same criteria, the identification of the level of maturity for this function corresponds to level 4. The maturity levels obtained for this function within the parameters of COBIT are shown in Table 3:

\begin{tabular}{l|c|c|c}
\multicolumn{1}{c|}{ Elements of Services } & Results & Normalization & Maturity \\
\hline Vector 1 - Architecture e Systems & $80 \%$ & 4.0 & 4 \\
\hline Vector 2 - Infrastructure Services & $76 \%$ & 3.8 & 4 \\
\hline Vector 3 - Innovation & $\%$ & & 4 \\
\hline Vector 4 - Managerial Method (ITIL) & $81 \%$ & 4.0 & 4 \\
\hline Vector 5 - Portfolio of Services & $80 \%$ & 4.0 & \\
\hline
\end{tabular}

Table 3 -Services Function 
The interpolation of the results shown in Table 3 shows that the level of maturity of the elements of the function Services are at level 4, mature, according to the convention adopted here. This indicates that the organizations surveyed are massively using the best market practices to manage IT in an appropriate manner and with higher standards of control.

\subsection{Quality and Security Function}

Quality and Security function is here analyzed in terms of the main results obtained by considering four basic vectors: (1) communication in IT, their metrics and indicators related to the business, (2) risk management framework; (3) structure and use of internal controls, and (4) the quality management of third parties and respective contracts.

We examine the suitability of these vectors for the specific regulatory environment in which each organization operates. The goal is to ensure that the services keep the quality with the necessary adherence of IT to business objectives, considering costs and deadlines for the tasks and project demands. Also, if IT products, whether produced internally or purchased in the market, are delivered to users and evaluated in terms of services and its expected quality. It is assumed that the accuracy in monitoring the quality should be the same for internal or external service providers and that user is always seen as a customer.

In terms of vector 1, communication in the IT business areas - Chart 13 - seems to be more introjective and with little socializing. The evidence appears in the results showing that just over $40 \%$ of CIOs responded to have quality indicators that support business processes. This figure rises slightly (44\%) for the surveillance function of aggressors and quality communication to users, but it remains below $40 \%$ when looking at performance monitoring of IT services in order to generate indicators for the daily business areas $(39 \%)$. 


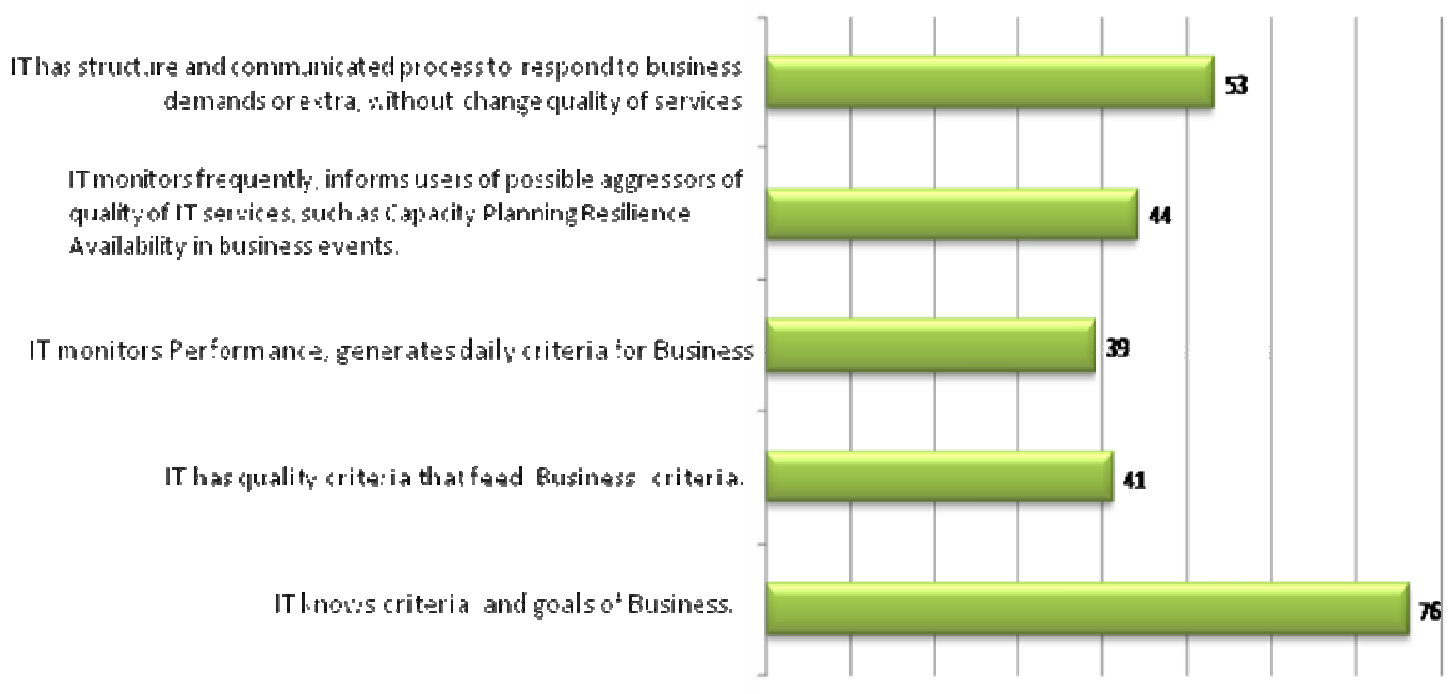

\section{Chart 13 - Communication of IT / Business}

The introjections of IT management in the organizations surveyed are most apparent when comparing these data with the results of knowledge about the indicators of IT business goals. In around $76 \%$ of organizations surveyed, CIOs say IT knows the indicators. However, such knowledge is not accompanied by the IT quality criteria that match the business. About $60 \%$ of organizations do not have such indicators. This fact has a strong implication on the issue of aligning IT with the business. In fact, if there were the sharing of results generated by the business indicators with indicators of IT quality, a better strategic alignment between both areas could happen, since the socialization of the results establishes a strong commitment and inspire greater cooperation between areas.

Regarding the second vector analysis, the risk management involving the maintenance of proper internal controls in IT, we can observe that there are internal controls of IT, formalized in $76 \%$ of organizations surveyed (Chart 15). This probably happens because of the adoption and use of management methodologies COBIT, ISO and BS $(34,32,30 \%$, respectively, seen in Chart11) by IT executives aimed at improving the governance environment, and the fact that more than $50 \%$ of organizations surveyed are subject to market rules for publicly traded companies.

It is remarkable that more attention is being given to internal controls in order to reach maturity in process control. Research shows that $64 \%$ of IT executives - Chart 14 - seek to understand the maturity level of its internal control processes through internal and external benchmarking (other organizations or organizations in the same conglomerate) and independent audits (52\%). The evaluation of internal controls is to identify potential risks of utility and effectiveness of controls in order to redirect the IT plan and improve the quality of the services provided. 
Although significant rate $(64 \%)$ of those who deem important to reach maturity in internal controls, this rate still appears to be relatively low given its importance as a factor in ensuring the quality of IT services.

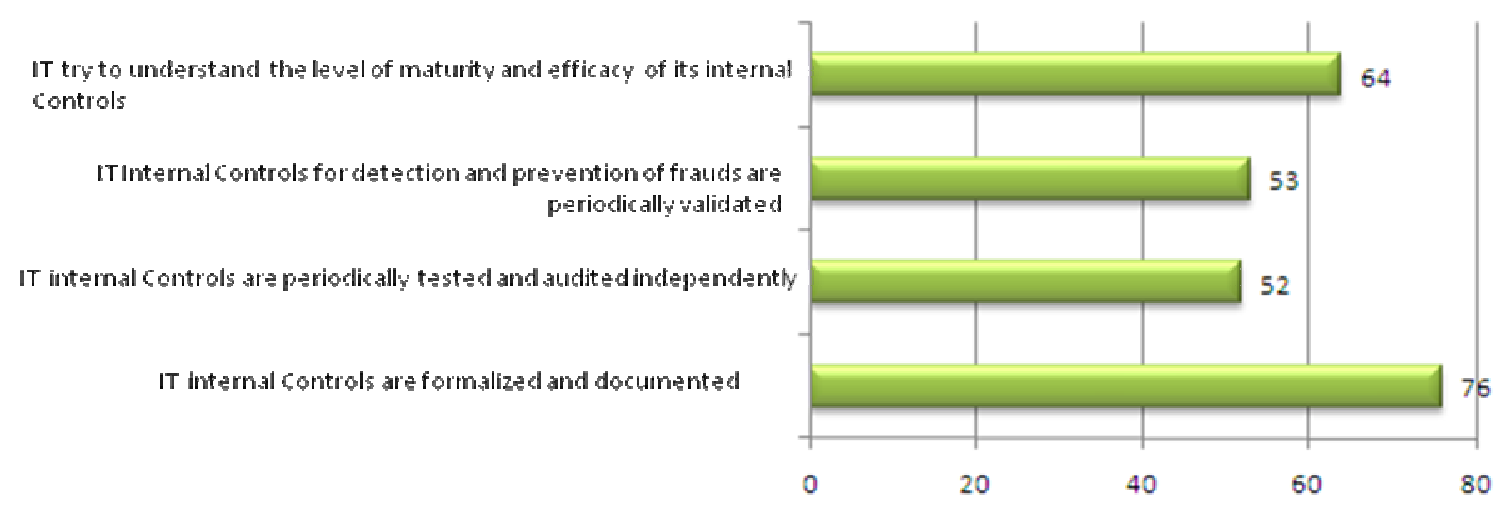

\section{Chart 14 - Internal Control Management}

The third vector of the Quality and Security assurance function refers to the quality management of third parties and their respective contracts. The verification of the profile of this vector is done by analyzing the management of outsourcing. The results indicate that just over $30 \%$ of respondents do not execute the management of such contracts - Chart 15 - or even consider them important. One of the reasons of the failure of management outsourcing perhaps lies in the fact that management is not from IT, but from another area, such as the Legal Department of the organization. Or, what would be less likely, IT executives assume self-sufficiency of their systems in use and new applications are developed internally, on demand, without external help.

We also inquired IT executives about their concerns with the contract management of outsourced projects and activities, as the fourth vector of this function. We can find that about $50 \%$ of them, in fact, does the management of these contracts, but only $20 \%$ give proper attention, making and updating their outsourcing processes 


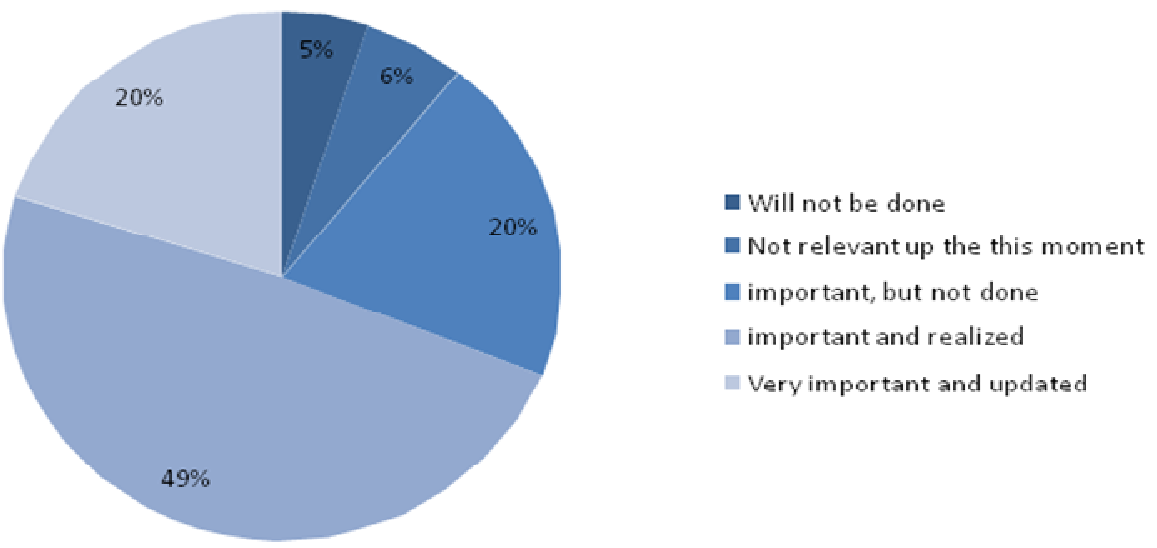

\section{Chart 15 - IT Management of Outsourced Contracts and Projects}

In relation to Service Level Agreements with providers, the survey results have shown that to ensure the quality of services, $54 \%$ of IT organizations establish Service Level Agreements with third-party providers. These are formal agreements and they reflect the negotiation between the requirements of the clients (users) and IT operational capability for a particular service. Although a trend in the use by the IT area, $36 \%$ of respondents declared that is an important type of agreement, however, not having yet implemented it.

The identification of the level of maturity according to COBIT (IGI, 2010) for the vectors of the Quality and Security Assurance function was made considering the same criteria used to identify the level of maturity in previous functions studied, taking into account the vectors: (1) Communication IT with the business, (2) risk management structure, (3) Structure of internal controls and IT (4) contract management of third parties. The maturity levels obtained for this function are shown in Table 4:

\begin{tabular}{l|c|c|c}
\hline \multicolumn{1}{c|}{$\begin{array}{c}\text { Elements of Quality and Security } \\
\text { Function }\end{array}$} & Results & Normalization & Maturity \\
\hline Vetor 1 - IT Communication & $76 \%$ & 3.8 & 4 \\
\hline Vetor 2 - Risk Management & $54 \%$ & 2.7 & 3 \\
\hline Vetor 3 - Internal Control Management & $76 \%$ & 3.8 & 4 \\
\hline $\begin{array}{l}\text { Vetor 4 - Third Parties Agreement } \\
\text { Manag. }\end{array}$ & $69 \%$ & 3.5 & 3 \\
\hline
\end{tabular}

Table 4 - Quality and Security Assurance Function

The analysis of the data in Table 4 indicates that there is a fairly balanced dispersion of maturity between intermediate and mature levels over the vectors of this function. While communication of IT with the business areas of the organization and 
management of internal control are already reaching maturity, risk management and third party contracts remain at intermediate levels of maturity.

\section{FINAL REMARKS AND CONCLUSIONS}

The main objective of this research is to determine whether IT in the 100 top organizations based in Brazil, classified in the Guia Exame - Maiores e Melhores/2008, is managed as a business, under the perspective of the IT executives. To this end, the research aimed to study how IT executives are managing the IT functions, where the Lutchen's (2003) gap can be detected.

Thus, we characterized a conceptual scheme placing the key functions of this research - Alignment, Management, Services and Quality and Security Assurance - as the elements of the IT Delivery Spectrum. We then identified the Lutchen's gap in those functions by determining the level of IT maturity for each function, using the version 4 of COBIT (IGI, 2010) adapted criteria as described in the methodology. Data collection was performed in a quantitative manner, with the Top 100 organizations based in Brazil, distributed over the 10 more representative economic sectors. Analysis and interpretation of survey data enabled us to reach some basic conclusions that show a context determined by the answers of IT executives of large global organizations, very close to the ones observed in the literature.

An accurate analysis of the results shows that IT executives, in this study, seem willing to be aligned to the business their IT areas support. But there is a significant difference between the reality and their wishes.

While the vast majority (63\%) claims to have a plan or comply with alignment between IT (ITSP) and Business (BSP) plans, a significant portion of them (37\%) does not recognize the alignment as an important factor in the management of IT activities. This dichotomy between the expected and observed alignment is also noted in the research by Luftman (2003), Zorello (2005) and Abreu and Fernandes (2008), whose findings indicate alignment problems, also point that organizations as a result, may be allocating IT resources inappropriately.

Given the less representative positioning of IT in the organizational hierarchy, IT strategies do not have the expected reach and effectiveness, and often are misaligned to business strategies. The subordination of IT to more tactical than strategic levels did not contribute to the adequate alignment of IT and respective control through commonly shared business indicators, such as the Balanced Scorecard as noted by Fernandes; Abreu (2008) .

In terms of maturity in the use of processes that ensure alignment of IT with business strategies, the results of this research also show consistency with the evidence described above, as these results indicate that the level of IT maturity lies in between maturity levels (2) and (3), under COBIT (ITGI, 2010) criteria. This means that the function Alignment (with business strategies) shows evidences that it is still incipient for some vectors, and in some others, is intermediately mature.

With respect to the Management function, one can notice that in terms of IT budget investments, results of this survey are consistent with other research, such as the Center for IT Studies at MIT (WEILL et al. 2002; Weill and Aral, 2006). Results of the 
research are fairly consistent regarding financial allocation of technologies and systems, upgrade of infrastructure, communication, training and technology innovation. Still, from the point of view of the management function, this survey results show that the elements of the governance cycle are documented, automated and disseminated at an intermediate level, considering the best practices. Thus, we can assume that the maturity of IT lies, among organizations researched, at the intermediate level (3), under COBIT (ITGI, 2010) maturity scale. This means that the management function shows evidence that its processes are more mature than the function alignment, but still at an intermediate level.

Concerning the function Services, despite the evidence of some discrepancies with the results of other global surveys, already mentioned, there are clear indications that the organizations surveyed seem to be running IT like a business. A major evidence is the administrative function of planning and control IT activities. It may be noted that the organizations surveyed, in general, apply processes, rules management, budgeting and costing and use parameters, measurable indicators and metrics control, proper of administrative procedures for any business.

Lutchen (2003) believes that the main contribution of services function is associated with how to accelerate and innovative organizations through consistent delivery of IT. Data from this study show that all the IT executives have adopted a model of management practices (whether ITIL, COBIT, PMI, ISO27001 or similar) to manage their services, demands, operations and assets. Among the listed practices, ITIL is the most widely adopted (almost 50\%) by IT executives. This shows that IT documents internal processes as standard models, but obliterates the creation of automated structures in IT based on the best market practices. It is also worth noting that data of services function, interpolated on the COBIT (ITGI, 2010) management maturity scale, indicates that the organizations surveyed are mature, at level maturity (4).

Finally, the function Quality and Security Assurance shows that a significant portion of IT executives are monitoring events, but it is not measuring the performance of IT as a whole. There are clear signs of individual control, such as monitoring and reporting of disrupting events (such as an incident and problems of management) to business managers (41\%), validation and periodic auditing of internal controls (50\%), requirement of SLAs (49 \%) and SOW (27\%) of suppliers. However, such control matters are still "compartmentalized" among the vectors that compound the function. They are not integrated, not coexisting in a coherent way allowing for indicating the overall performance of IT.

Assessing the maturity of existing quality processes in the organizations surveyed, according to COBIT (ITGI, 2010) maturity scale, there is evidence that the quality and security function is located between levels of maturity (3) and (4). In other words, managing the quality function of IT can be ranked between the intermediate and mature levels.

In general terms, as it is designed, IT management tends to consume more time of IT executives dealing with routine tasks than with innovation, which seems to be no priority among them. The results indicate that most executives plan innovation projects for the future more than the present. IT executives prefer partnering leadership in innovation than taking a proactive leadership role. 
Considering that three of the four functions evaluated in this study show rates of maturity between incipient and intermediate and only one function shows a higher level of maturity, we can say that IT is managed, by the majority of IT executives in organizations located in Brazil, much more as a "solution provider" than an innovation tool or less yet as a competitive differentiator. IT is, thus, dedicated only to fulfilling a functional task in the structure of organizations.

For better clarity, we design a chart showing the level of maturity of the functions analyzed in this investigation. Figure 2 shows iconographically the specific levels of maturity for the IT functions Alignment, Management, Services and Quality \& Security, summarizing the Lutchen's gap.

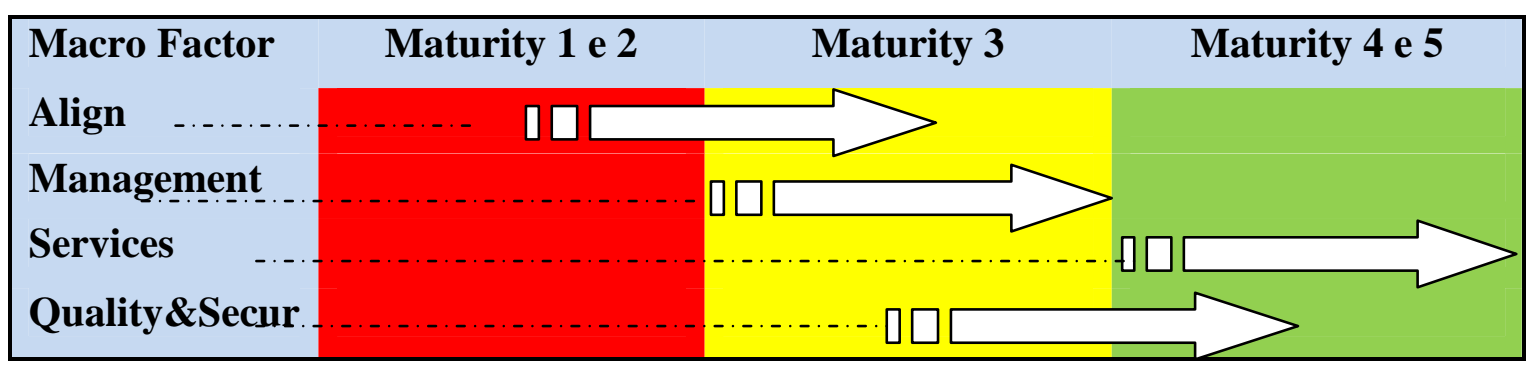

Figure 1 - Summarizing maturity in IT functions

A summary of the results shown in Figure 2 demonstrates that the profile of IT management in the top 100 companies based in Brazil does not have the maturity level needed to systemically integrate the objectives, goals and business processes. It seems that the "operational view of IT" advocated by Lutchen (2003) is detected as the emphasis of the IT management model among the researched organizations.

Thus, similarly to the requirements for effective management of IT mentioned and discussed by Shpilberg et al. (2007) and Lutchen (2003), in the daily life of organizations, there is evidence that IT plays a purely operational role, that is, a service supplier.

In the context of the results discussed so far, we cannot forget to notice that, although there are management tools and they are being used, the role of IT management, a necessary link between the functions Alignment and Services, IT management does not show evidence of the expected maturity to raise the level of maturity of the Alignment function, the most incipient of the functions evaluated. Thus, it is evident that the alignment remains as the main bottleneck of the IT functions, characterizing the Lutchen's (2003) gap. There seems to be the IT functional gap, which obliterates efforts to manage IT as a business.

Here, according to Lutchen, IT should have greater influence on business processes and the overall performance of the organization. Looking at the results of this research, we noted that there are several inefficiencies in management, governance and control and use of quality indicators creating barriers for IT to play its influencing role in the overall business performance of the organization.

Despite of the higher level of maturity in other functions, results for the Services function, if compared with the Alignment function, again confirms the Lutchen's (2003) gap, considering the dichotomy between what happens at the intermediate level of the relationship of IT with business managers. It seems clear, therefore, that aligning IT 
processes with business needs, delivering quality services under the best practices and distributing costs over users' departments, is a less common managerial practice in larger organizations based in the country. Finally, it is conclusive, by the results of the survey, that the IT managerial gap, appointed by Lutchen, is detected in the organizations surveyed.

The limitations encountered in this research are related to the fact that the survey had been answered only by IT executives and not additionally by business executives. This format would allow a more specific understanding than if problems associated with both sides of the IT management (providers and users) had been considered. For future work, therefore, it is also suggested to apply the research among business executives, to confirm if the weaknesses appointed by IT people are similar to the ones eventually appointed by business people.

\section{REFERENCES}

Albertin, A. L.; Sanchez, Otávio Próspero (Org.).(2008) Outsourcing de TI: impactos, dilemas, discussões e casos reais. Rio de Janeiro: FGV.

Borland. A (2006) Comprehensive technology portfolio management process. Borland IT Management \& Governance Solution, p. 3-21. Disponível em: http://www.borland.com/resources/en/pdf/white_papers/technology_portfolio_managem ent.pdf Acesso em 10 Mar. 2010.

Brege, Staffan; Brehmer, Per-olof; Rehme, Jakob. (2008) Managing supplier relations with balanced scorecard. Int. J. Knowledge Management Studies, v. 2, n. 1, p.147161.

Corrêa, P. M. (2006) Um estudo sobre a implantação da governança de TI com base em modelos de maturidade. Centro Estadual de Educação Tecnológica Paula Souza. Disponível em: http://www.centropaulasouza.sp.gov.br/ Posgraduacao/Trabalhos/ Dissertacoes/DM_Tecn_Paulo_Correa.pdf. Acesso em 10 Mar. 2010.

Craig, David; Tinaikar, Ranjit. (2006) Divide and Conquer: Rethinking IT strategy. McKinsey Quarterly. Disponível em: http://www.mckinseyquarterly.com/ Divide and_conquer_Rethinking_IT_strategy. Acesso em: 26 Fev. 2010.

Fernandes, Aguinaldo Aragon; ABREU, Vladimir Ferraz de. (2008) Implantando a governança de TI: da estratégia à gestão de processos e serviços. 2. ed. Rio de Janeiro: Brasport.

IDC. (2006) IT project and portfolio management and the application life cycle: understanding the market and enabling IT / business coordination. Framingham, 2006. Disponível em: http://www.cio.co.uk/whitepapers/3684/it-project-and-portfoliomanagement-and-the-application-life-cycle/. Acesso em 08 Set. 2010.

COBIT Framework for IT Governance and Control - version 4. IT Governance Institute - ITGI: Rolling Meadows, (2010) Disponível emhttp://www. http://www.isaca.org/Knowledge-Center/cobit/Pages/ Overview.aspx.. Acesso em: 12 Mar. 2010.

Lobler, Mauri Leodir; Bobsin, Débora; Visentini, Monize Sâmara. (2008) Alignment between the strategic business plan and the plan of information technology at 
companies: the comparative analysis through the maturity level and critical sucess factors. Journal of Information Systems and Technology Management, v. 5, n. 1, 2008, p. 37-60.

Luftman, J.N. (2003) Managing the information technology resource: leadership in the information age. Rio de Janeiro: Prentice Hall.

Lutchen, Mark. (2003) Managing IT as a business: a survival guide for CEOs. New York: John Wiley and Sons.

Marwaha, Sam; Seth, Parul, Tanner, David W. (2005) What global executives think about technology and innovation. McKinsey Quarterly. Disponível em: http://www.mckinseyquarterly.com/What_global_executives think_about_technology and innovation_1653. Acesso em: 25 Fev. 2010.

Marwaha, Sam; Willmott, Paul. (2005) Managing IT for scale, speed and innovation. McKinsey Quarterly. September, p. 15-21. Disponível em: http://www.mckinsey quarterly.com/Managing_IT_for_scale_speed_and_innovation_1848. Acesso em: 25 Fev. 2010.

Miles, M. B., Huberman, A. M. (1994) Quantitative data analysis: an expanded sourcebook. 2 ed. Thousand Oaks: Sage.

Prahalad, C.K. Krishnan, M.S. (2002) The dynamic synchronization of strategy and information technology. MIT Sloan Management Review, v. 43, n. 4, p. 24-33.

Prahalad C.K. (2006) CIOs Hold Key to Operational Excellence. Optimize. v.5, n.5, p.66.

Porter, M. E. (1986) Estratégia competitiva: técnicas para análise da indústria e da concorrência. Rio de Janeiro: Campus.

Rezende, D.A. (2002) Tecnologia da informação integrada à inteligência empresarial: alinhamento estratégico e análise da prática nas organizações. São Paulo: Atlas.

Rodrigues, L.C.; Maccari, E.; Simões, S.A. (2009) O Desenho da Gestão da Tecnologia da Informação nas 100 Maiores Empresas na Visão dos Executivos de TI. Revista de Gestão da Tecnologia e Sistemas de Informação, v.6, n.3, p. 483-506.

Shpilberg, David.; Berez, Steve, Puryear, Rudy; Shah, Sachin. (2007) Avoiding the alignment trap in information technology. MIT Sloan Management Review, v. 49, n. 1, p. 51-58.

Takanen, Tiina. (2008) The changing role of the CIO - Is CIO and IT expert or a business executive? Disponível em: http://hsepubl.lib.hse.fi/FI/ethesis/pdf/12001/hse ethesis_12001.pdf. Acesso em: 06 Nov. 2010.

Weill, Peter; Aral, Sinan. (2006) Genereting Premium Returns on your IT Investments. MIT Sloan Management Review, v. 47, n. 2, p. 39-48

Weill, Peter; Ross, Jeanne (2004) IT Governance. Boston: Harvard Business School Press.

Weill, Peter; Subramani, Mani; Broadbent, Marianne (2005). Building IT infra-structure for strategic agility. MIT Sloan Management Review, v. 44, n. 1, p. 57-65, 2002. ZORELLO, G. Metodologias COBIT e ITIL e as perspectivas do Modelo de 
748 Simões, S. A., Rodrigues, L. C., Maccari, E. A., Pereira, M. F.

Alinhamento Estratégico de TI. XII SIMPEP, p.2-4 Disponível em: <http://www. consulting.com.br/edsonalmeidajunior/admin/downloads/cobit.pdf $>$. Acesso em $20 \mathrm{dez}$. 2010. 